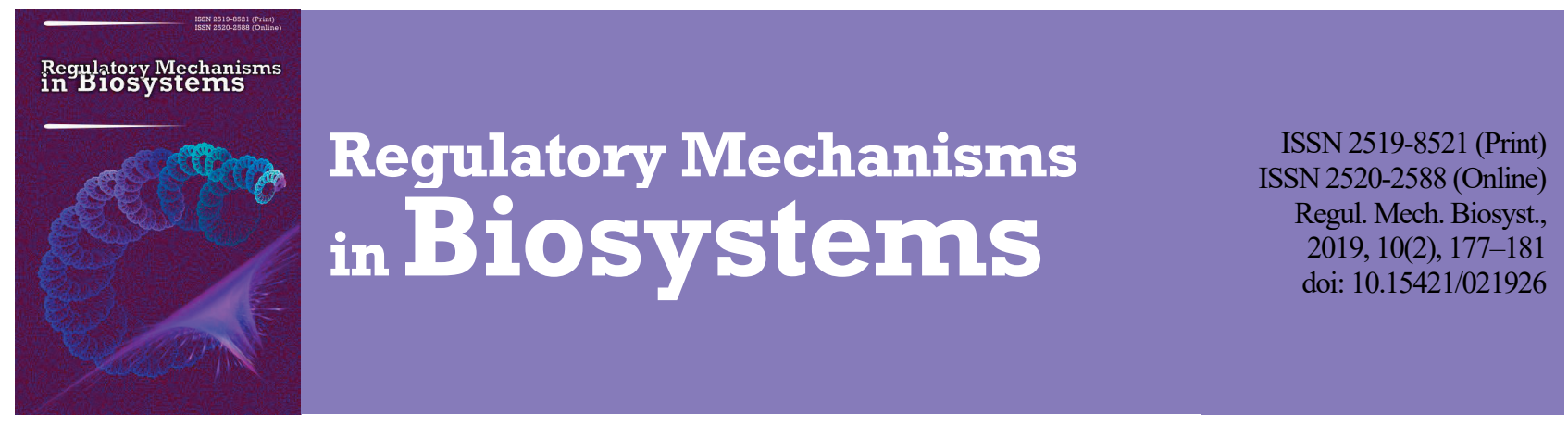

\title{
Physiological relationship between content of certain microelements in the tissues of different anatomic sections of the organism of honey bees exposed to citrates of argentum and cuprum
}

\author{
I. Kovalchuk*, I. Dvylyuk*, Y. Lecyk*, I. Dvylyuk**, B. Gutyj** \\ *Institute of Anomal Biology, National Academy of Agrarian Sciences of Ukraine, Lviv, Ukraine \\ **Stepan Gzhytskyi National University of Veterinary Medicine and Biotechnologies, Lviv, Ukraine
}

Article info

Received 19.04.2019

Received in revised form 23.05.2019

Accepted 27.05.2019

Institute of Animal Biology of NAAS, V. Stus st., 38

Lviv, 79034, Ukraine,

Tel.: +38-050-370-74-11.

E-mail:dvylvukivanna@ukr.net

Stepan Gzhytskyi National

University of Veterinary

Medicine and Biotechnologies,

Pekarska st., 50,

Lviv, 79010, Ukraine.

Tel. $+38-068-136-20-54$.

E-mail:bvh@ukr.net

Kovalchuk, I., Dvylyuk, I., Lecyk, Y., Dvylyuk, I., \& Gutyj, B. (2019). Physiological relationship between content of certain microelements in the tissues of different anatomic sections of the organism of honey bees exposed to citrates of argentum and cuprum. Regulatory Mechanisms in Biosystems, 10(2), 177-181. doi:10.15421/021926

The study was conducted on honey bees of the Carpathian breed on the basis of the apiary of S. Z. Gzhytskyi Lviv National University of Veterinary Medicine and Biotechnologies. The bees were kept in 8-frame beehives with size of the frame of $435 \times 300 \mathrm{~mm}$. The study was undertaken in the summer-autumn period. A total of 5 groups of bee families were formed according to the analogue principle, with three families of bees in each group. Control (I) group received sugar syrup in $1: 1$ concentration (1000 mL/group/week). In the experimental (II) group, $\mathrm{Ag}$ was added to the syrup in amount of $0.5 \mathrm{~mL} / \mathrm{g}$ of the sugar syrup; in III experimental group - in similar conditions Ag was added in $1 \mathrm{mg} / \mathrm{L}$ amount; IV group received sugar syrup with $\mathrm{Cu}$ in $0.5 \mathrm{mg} / \mathrm{L}$ amount; $\mathrm{V}$ experimental group - $\mathrm{Cu}$ in amount of $1 \mathrm{mg} / \mathrm{L}$ of sugar syrup. Microelements were added to sugar syrup in the form of citrates obtained using method of nanotechnology, developed by the company Nanomaterials and Nanotechnologies in Kyiv. The period of monitoring lasted 28 days with 7 days interval of preparation. Inter-group and anatomic differences were found in content of certain mineral elements in the tissues of the head, thorax and abdominal sections of the honey bees in conditions of feeding with citrates of argentum and cuprum in sugar syrups. Under the influence of citrate of argentum in amount of 0.5 and $1.0 \mathrm{mg} / \mathrm{L}$ of sugar syrup, content of ferrum increased in the tissues of the head and abdominal sections, though it decreased in the thorax, content of cuprum decreased in the tissues of head, thorax and abdomen, content of zinc increased in the tissues of head and thorax, though it decreased in the abdomen, content of lead and cadmium reduced in the tissues of all anatomic sections of the organism of honey bees. Under the influence of cuprum in amount of 0.5 and $1.0 \mathrm{mg} / \mathrm{L}$ of sugar syrup, content of ferrum reduced in the tissues of the head, though it increased in the tissues of thorax and abdomen, content of cuprum increased, and the content of zinc, lead and cadmium reduced in the tissues of all anatomic sections of honey bees. According to the results of the study, the determining effect of feeding of honey bees on the optimization of the parameters of mineral metabolism in different anatomic sections of the organism of bees is discussed.

Keywords: zinc; lead; cadmium; ferrum; the tissues of head; abdominal and thorax section

\section{Introduction}

Using modern methods of maintaining and care of bee families, the issue of their rational provision with nutrition arises. It is important to influence the feeding regime of bee families by providing them with an optimum amount of diet for fulfilling their needs in different periods of the season, accurately controlling food reserves in winter, providing bees with protein-containing fodder over the period of protein deficiency in nature, and creating conditions which would encourage bees for active work (Brodschneider \& Crailsheim, 2010; Kovalskyi et al., 2018). For normal vitality and reproduction, a bee family, regardless of period of season, should receive food with proteins, fats, carbohydrates, mineral salts, vitamins and water (Tyshhenko, 1986; Lebedev \& Bilash, 1991; Kovalchuk \& Fedoruk, 2008). For intensive concentration of strength in spring, consuming protein-containing fodders is one of the most important factors for bee families. For the development and functioning of mandible and pharyngological glands which produce components of royal jelly for feeding larvae, bees should consume complete protein fodder (according to data of H. P. Taranov, pharynx glands of young bees develop only if a digestible protein is present in their diet). In our case, bees use reserves of their organism, accumulated in the fat body, which causes rapid exhaustion of bees, reduction of their life span and therefore abrupt weakening of the families over the early spring period. Therefore, it is necessary to ensure stable feeding of bees and stable metabolism in their organism, where macro- and microelements are essential. A number of studies (Bogdanov et al., 2007) indicate that clinical condition, resistance, productivity and quality of products, reproductive function of humans and animals completely depend on provision of their organism with biologically active substances, including microelements. One of the leading methods of increasing resistance of bee families to negative external factors (Conti \& Botre, 2001) and, as a result, ecological safety of the products of beekeeping is using mineral complexes.

Over recent decades both in global and domestic practice, innovational nanopreparations on the basis of mineral elements - nanocompounds have been developed. Their use in different doses and forms conditions their effect on physiological-biochemical processes in the organism (Dolaychuk et al., 2015). Particularly, in mineral nutrition of animals, such additives as nanocarboxilates of metals $\mathrm{Zn}, \mathrm{Fe}, \mathrm{Mg}, \mathrm{Cr}$, $\mathrm{Cu}, \mathrm{Co}, \mathrm{Mn}$, and also Se, I, Ge and others are being introduced. Numerous studies have proven that nano aqua-chelates of biotic macro- and microelements have a high stimulating effect, are low-toxic, and are 
quickly and efficiently digested in the organism (Chekman, 2011). Analysis of recent studies in veterinary medicine (Borysevych et al., 2012) indicates a significant dominance of using the elements of nutrition in the form of nano aqua-chelates for increasing metabolic activity, stimulation of metabolic process of the organism of animals, which at the same time manifest preventive-treatment efficiency. The high physiologic activity of these microelements is related first of all to their participation in synthesis of certain enzymes, vitamins and hormones, which can stimulate protein, carbohydrate and lipid metabolism.

It has been experimentally proven that depending on the dosage, argentum and cuprum have bactericidal, immune-stimulating, fungicidal properties (Anton et al., 1994; Baker et al., 1999). Cuprum is present in the system of anti-oxidative protection of the organism as a co-factor of enzymes of superoxide dismutase, which takes part in neutralizing free radicals of oxygen, in processes of cellular respiration, and is included in the content of enzymes of cytochrome oxidase, tyrosinase and others.

As for the physiological effect of argentum on the organisms of humans and animals, it should be noted that ions of this ultra microelement take part in metabolic processes of the organism. Depending on concentration, its cations can both stimulate and inhibit activity of a number of enzymes. Under the impact of argentum, the intensity of oxide phosphorylation in mitochondria of the brain increases, as well as content of nucleic acids (Linder, 2002; McDowell, 2003). In the form of ions, it has bactericidal, notable anti-fungicidal and antiseptic effects and is a highly efficient disinfectant against pathogenic microorganisms which cause acute infections. Furthermore, heightened interest of scientists in argentum is explained not only by intense anti-bacterial and antiviral properties, but also by the fact that recently its effect on the organism as a microelement necessary for normal functioning of the organs and systems and also its immune-improving properties have been determined. Argentum is considered an effective preparation which improves immunity and actively affects pathogenic bacteria and viruses. However, the physiological impact of new compounds of these elements, introduced to nutrition in the form of citrates, on the distribution of other metals in the tissues of different anatomic sections of the organism of honey bees has not been yet studied. Therefore, the objective of the study was the synergic and antagonistic effect of different doses of citrates of argentum and cuprum on content of such elements as $\mathrm{Zn}, \mathrm{Fe}$, $\mathrm{Cu}, \mathrm{Cr}, \mathrm{Co}, \mathrm{Pb}$ and $\mathrm{Cd}$ in the tissues of the head, thorax and abdomen of honey bees in the conditions of their addition to sugar syrup.

\section{Material and methods}

The research were conducted on honey bees of the Carpathian breed on the basis of an apiary of S. Z. Gzhytskyi Lviv National University of Veterinary Medicine and Biotechnologies. The bees were kept in 8-frame beehives with size of the frame equaling $435 \times 300 \mathrm{~mm}$. A total of 5 groups of bee families was formed according to the principle of analogue by productivity and strength of family; with three bee families in each group. Control (I) group received sugar syrup in $1: 1$ concentration (1000 mL/group/week). In the experimental (II) group, $\mathrm{Ag}$ was added to the syrup in amount of $0.5 \mathrm{~mL} / \mathrm{g}$ of the sugar syrup; in III experimental group - in similar conditions Ag was added in $1 \mathrm{mg} / \mathrm{L}$ amount; IV group received sugar syrup with $\mathrm{Cu}$ in $0.5 \mathrm{mg} / \mathrm{L}$ amount; $\mathrm{V}$ experimental group - $\mathrm{Cu}$ in amount of $1 \mathrm{mg} / \mathrm{L}$ of sugar syrup. Microelements were added to sugar syrup in the form of citrates obtained using the method of nanotechnology (Nanomaterials and Nanotechnologies Company, Kyiv). The monitoring period lasted 28 days with a 7 day interval for preparation. The research was conducted according to the "General ethical principles of experiments on animals" (Kyiv, 2001).

On 28th day of the studies, out of each family of honey bees, 100 worker bees of each group were extracted for preparing homogenates of the tissues of separate anatomic sections of their organism. Samples of bees were dissected in laboratory conditions into certain anatomic sections: head, thorax and abdominal sections; out of each of them, three parallel samples from each group were formed with $1 \mathrm{~g}$ mass and homogenates were prepared. The obtained homogenates of separate anatomic sections of honey bees were processed using dry ashing method in porcelain crucible in a muffle furnace at temperature regime from $100^{\circ} \mathrm{C}$ at initial stage to $400-450{ }^{\circ} \mathrm{C}$ at the final stage of ashing. Duration of the ashing process was 10-12 h. After mineralization, ash was dissolved in $10 \mathrm{~mL}$ of $6 \mathrm{H} \mathrm{HCL}$, filtrated, and poured into test tubes for determining content of $\mathrm{Fe}, \mathrm{Cu}, \mathrm{Zn}, \mathrm{Co}, \mathrm{Cr}, \mathrm{Pb}, \mathrm{Cd}$. Concentration of each of the mentioned microelements was determined according to the computer program on the atomic-absorption spectrophotometer SF$115 \mathrm{PK}$ and expressed in $\mathrm{mg} / \mathrm{kg}$ of natural mass.

The obtained digital material was analyzed using the method of variability statistics and ANOVA. We calculated mean arithmetic values $(x)$ and standard errors of mean arithmetic values $( \pm$ SE) of the content of the elements in the tissues of different anatomic sections of the organism of honey bees. Mathematical analysis of the results was performed statistically using Statistica 6.0 (StatSoft Inc., USA) program pack. Results of mean arithmetic values were considered statistically probable at $\mathrm{P}<0.05$.

\section{Results}

According to the results of the conducted studies, we determined certain differences of content of $\mathrm{Fe}, \mathrm{Zn}, \mathrm{Cu}, \mathrm{Co}, \mathrm{Cr}, \mathrm{Pb}, \mathrm{Cd}$ in the tissues of separate anatomic sections of the organism of honey bees in conditions of feeding them with sugar syrup with different doses of citrates of $\mathrm{Ag}$ and $\mathrm{Cu}$. It should be noted that feeding sugar syrup with both 0.5 and $1.0 \mathrm{mg} / \mathrm{L}$ of argentum in the form of citrate was characterized by increase in the content of ferrum in homogenate of the tissues of the head of honey bees from II and III groups compared to the control group (Fig. 1). Thus, in these tissues of III experiment group, Fe concentration was probably by $24.2 \%(\mathrm{P}<0.05)$ higher against the background of decrease of this element in IV and V groups of honey bees which received $\mathrm{Cu}$ citrate. The studies from previous years have revealed that content of $\mathrm{Fe}$ in the tissues of adult bees is highest in the thorax muscles and lowest in the tissues of legs and wings, which is related to anatomic peculiarities and different metabolic activity in the tissues of these organs.

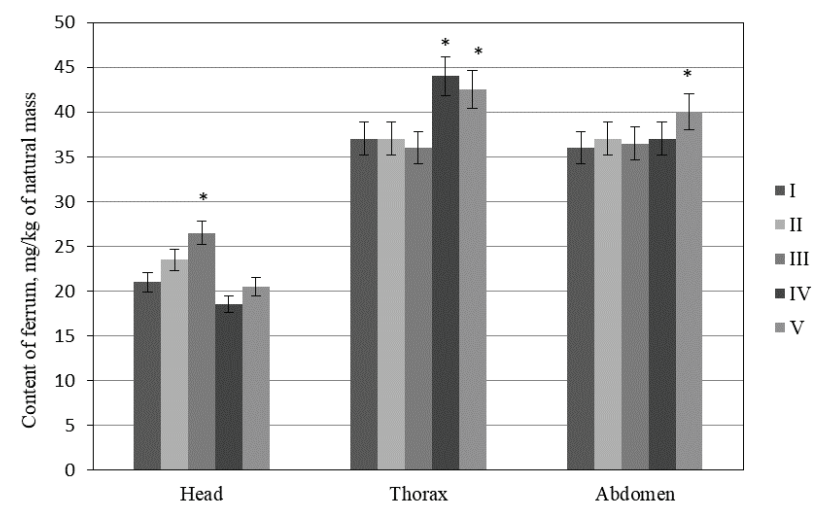

Fig. 1. Content of ferrum in tissues of the organism of honey bees ( $\mathrm{mg} / \mathrm{kg}$ of natural mass, $\mathrm{x} \pm \mathrm{SE}, \mathrm{n}=3$ ): in this and other figures * $-\mathrm{P}<0.05, * *-\mathrm{P}<0.01$

In the tissues of the thorax section of the experimental groups IV and $\mathrm{V}$, we observed heightened content of ferrum compared to the control. Particularly, increase in content of this element was recorded in samples of the tissues of thorax section of bees from IV and V groups, by 1.2 and 1.1 times respectively $(\mathrm{P}<0.05)$ compared to the control. It was characteristic that in samples of the tissues from the abdominal section of the organism of honey bees, higher content of ferrum was determined in the tissues of bees from experimental group V $(\mathrm{P}<0.05)$ compared to the control.

The level of $\mathrm{Cu}$ in the tissues of different anatomic sections of the organism of bees from II and III experimental groups did not significantly change. Content of this element higher by $1.2-1.4$ times $(\mathrm{P}<0.05)$ compared to the control was determined in all tissues of $\mathrm{V}$ experimental group, and for abdominal section - IV group, which indicates possible digestion of cuprum with syrup in the tissues of these sections. In the tissues of the head, we observed probably higher content of $\mathrm{Zn}$ in II $(15 \%-\mathrm{P}<0.05)$ and III $(16 \%-\mathrm{P}<0.01)$ experimental groups against 
the background of lower content in IV $(24 \%-\mathrm{P}<0,01)$ and V $(19 \%-$ $\mathrm{P}<0.01$ ) groups compared to the control.

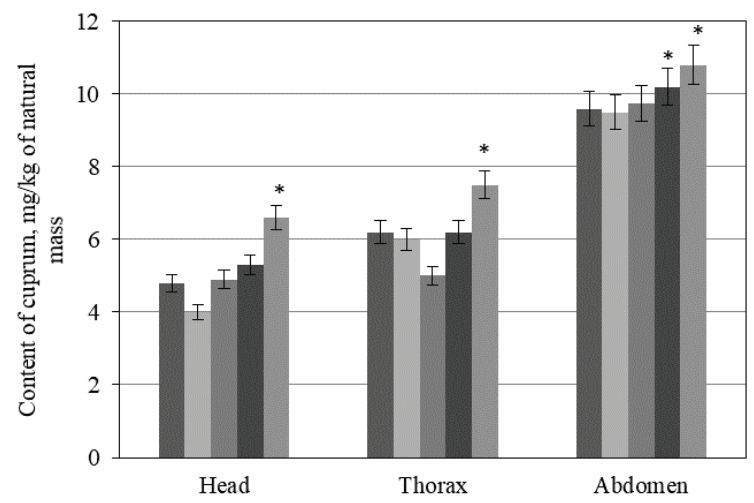

- I

II

III

IV

$\mathrm{V}$

Fig. 2. Content of cuprum in the tissues of the organism of honey bees $(\mathrm{mg} / \mathrm{kg}$ of natural mass, $\mathrm{x} \pm \mathrm{SE}, \mathrm{n}=3$ )

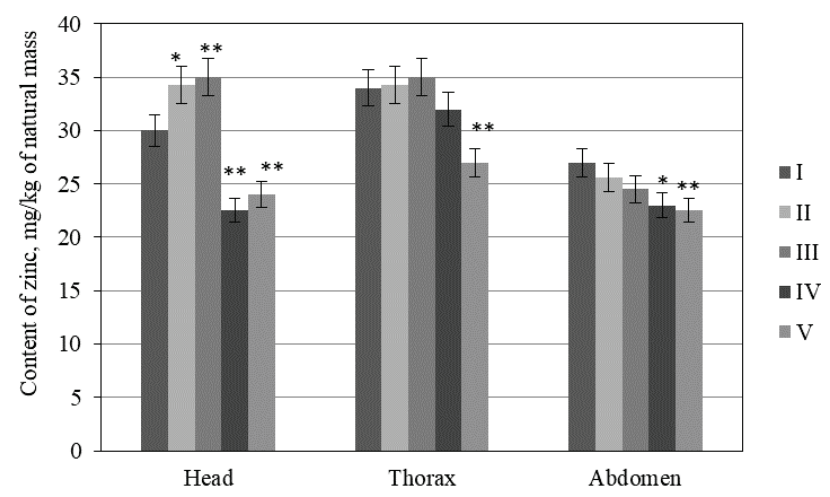

Fig. 3. Content of zinc in the tissues of the organism of honey bees $(\mathrm{mg} / \mathrm{kg}$ of natural mass, $\mathrm{x} \pm \mathrm{SE}, \mathrm{n}=3$ )

At the same time, level of $\mathrm{Zn}$ in the tissues of the thorax section of the bees significantly did not change in II and III groups. The level of this element lower by 7 and $19 \%(\mathrm{P}<0.01)$ compared to the control was determined in the tissues of the thorax section in IV and V experimental groups. The lowest level of this element was observed in the tissues of the abdomen of bees from II, III, IV $(\mathrm{P}<0.05)$ and V ( $\mathrm{P}<$ 0.01) experimental groups compared to the control.

According to the results of the study, an increase in $\mathrm{Cr}$ level in the tissues of head and thorax was determined in bees of III, IV and V experimental groups, though the differences were not significant (Fig. 4).

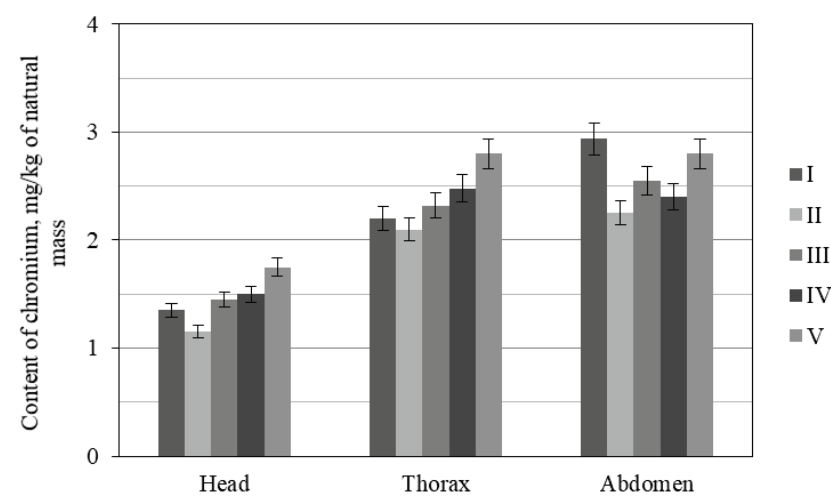

Fig. 4. Content of chromium in the tissues of the organism of honey bees $(\mathrm{mg} / \mathrm{kg}$ of natural mass, $\mathrm{x} \pm \mathrm{SE}, \mathrm{n}=3$ )

It was determined that feeding with sugar syrup with Ag substrate conditioned an insignificant decrease in Co in the tissues of the head of bees from II and III groups at a tendency towards increase in the content of this element in the thorax (Fig. 5). Instead, in bees given sugar substrate with $\mathrm{Cu}$ citrate, we observed an insignificant increase in $\mathrm{Co}$ in the tissues of the head and abdominal section of bees from IV and V $(\mathrm{P}<0.05)$ experimental groups with reduction in the thorax compared to the control.

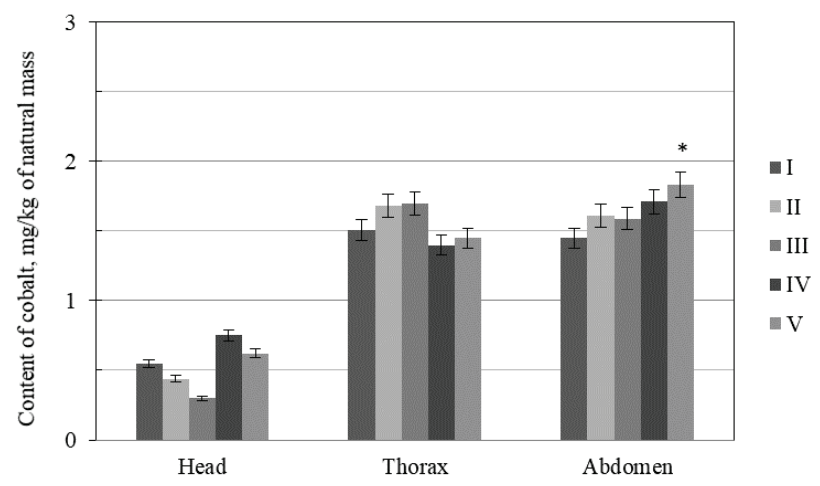

Fig. 5. Content of cobalt in the tissues of the organism of honey bees ( $\mathrm{mg} / \mathrm{kg}$ of natural mass, $\mathrm{x} \pm \mathrm{SE}, \mathrm{n}=3$ )

According to the results of the research, we found an antagonistic effect of citrates of $\mathrm{Ag}$ and $\mathrm{Cu}$ in the metabolic process on cumulative property of such toxic metals as $\mathrm{Pb}$ and $\mathrm{Cd}$ (Fig. 6, 7).

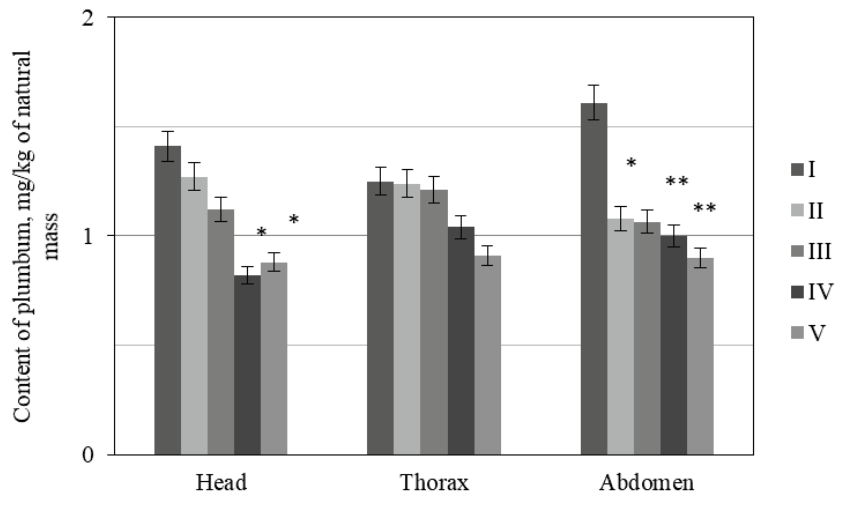

Fig. 6. Content of plumbum in the tissues of the organism of honey bees ( $\mathrm{mg} / \mathrm{kg}$ of natural mass, $\mathrm{x} \pm \mathrm{SE}, \mathrm{n}=3$ )

Thus, $\mathrm{Pb}$ concentration insignificantly decreased in homogenate of the tissues of the head of bees from II and II experimental groups, compared to the control. Differences between these groups did not exceed the values of mean statistical deviations. It should be noted that the highest activity of reducing $\mathrm{Pb}$ content in the tissues of the head was observed in IV and V experimental groups, where its content probably decreased by 1.7 and 1.6 times $(\mathrm{P}<0.05)$ respectively.

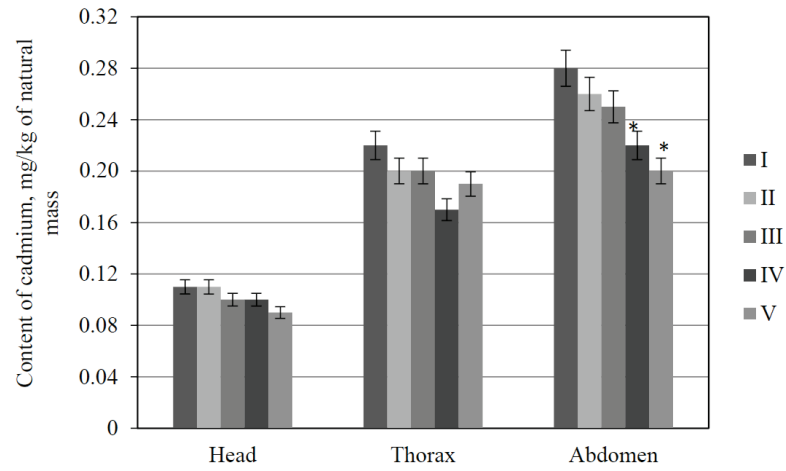

Fig. 7. Content of cadmium in the tissues of the organism of honey bees $(\mathrm{mg} / \mathrm{kg}$ of natural mass, $\mathrm{x} \pm \mathrm{SE}, \mathrm{n}=3$ )

In the tissues of the thorax we observed intergroup fluctuations of content of $\mathrm{Pb}$ and $\mathrm{Cd}$ without significant values for all experimental groups compared to the control. At the same time, in the tissues of the abdomen of bees of II and III groups, content of $\mathrm{Pb}$ decreased, and in IV 
and $\mathrm{V}$ experimental groups, use of $\mathrm{Cu}$ citrate for feeding was characterized by lower level of $\mathrm{Pb}(\mathrm{P}<0.001)$ and $\mathrm{Cd}(\mathrm{P}<0.05)$ compared to the control, which indicates a more manifested antagonistic effect of cuprum in the used concentrations on accumulation of $\mathrm{Pb}$ and $\mathrm{Cd}$ in these tissues of bees.

\section{Discussion}

It seems that increase in the daily consumption of ferrum by 7-16 times compared to the physiological need causes slowing of absorption of cuprum, manganese and cobalt, and therefore their deficiency in the organism. However, absorption of transported ferrum by mitochondria of erythrocytes significantly reduces in case of acute deficiency of cuprum (Finch \& Huebers, 1986). Perhaps, such relations are conditioned by separate aspects of interaction of these microelements, because analysis of cause-effect dependencies of content of these elements indicates their re-distribution in the organism at effect of various factors.

Cuprum takes part in the process of photosynthesis and affects digestion of nitrogen by plants. However, excessive concentrations of cuprum inhibit metabolic processes in the organism. In the organism of bees, potential places of accumulation of cuprum and its metabolites, except the large intestine, can be nerve nodes and the fat body. The high content of cuprum in the tissues of the abdominal section of the organism of honey bees which received $1 \mathrm{mg}$ of cuprum had an obvious dependence on the dose of consumed additives and was highest compared to other anatomic sections.

The literature data have no clear answer on effect of interaction between $\mathrm{Zn}$ and $\mathrm{Cu}$. Most of the data indicate their antagonism - content of cuprum in blood serum and liver linearly decrease with increase in logarithm of zinc concentration. Triple interaction between zinc, cuprum and food protein can cause deficiency of cuprum, especially at high levels of introduction of zinc and deficiency of proteins. In the case of increasing content of $\mathrm{Zn}$ in the diet 5-20 mg per a day, consumption of $\mathrm{Cu}$ for maintaining its balance should be increased by $60 \%$ (Mazo \& Shyrina, 2005). Excess of cuprum causes deficiency of zinc and molybdenum, leading to immunological disorders conditioned by lack of zinc. It was characteristic that feeding with citrates of $\mathrm{Ag}$ and $\mathrm{Cu}$ affected the level of zinc in the tissues of anatomic sections of honey bees in different ways. Particularly, the effect of cuprum citrate was characterized by antagonistic effect on zinc content in the tissues of the head, thorax and abdomen.

Intergroup differences in content of $\mathrm{Cr}$ in the mentioned sections are possibly related to effect of adding citrates on digestion and accumulation of $\mathrm{Cr}$ in these tissues, and also to competing metabolic effect of this element in the organism of bees. The interaction of $\mathrm{Cr}$ with other elements which are introduced with fodder and water into the organism of honey bees should not be disregarded, for mineral composition of pollen of different plants, including melliferous plants, significantly differ (Vincent, 2007; Iskra et al., 2014). As we know, physiological concentration of $\mathrm{Cr}$ in the tissues and liquids intensifies metabolic processes, including mineral metabolism in the organism (Anderson, 1987). However, at its excessive introduction into the organism of animals, no stimulating effect of chromium was observed. Changes in content of chromium in the tissues of the head of honey bees manifested to a higher extent than in the tissues of the thorax and abdomen.

Because it was proved that accumulation of certain elements in the organism of honey bees depends on their age, physiological condition, level of mineral, protein and carbon nutrition, their content in the organism can be higher or lower than in melliferous plants (Vishchur et al., 2016). However, during processing of nectar into honey, the content of macro- and microelements in it reduces, which is related to the specific filtrating capacity of the wall of the honey stomach of honey bees. Due to this fact, together with water, which is absorbed by hemolymph and the content of the crop, metals are also transported through its walls. Partly they are accumulated in the fat body and other anatomic structures of the organism of insects. Certain amounts of them are produced by the excretory organs. Plumbum and cadmium accumulate the most in the rectal glands of honey bees, which affects increase of water content in them. Obviously it appears due to the inhibiting function of the rectal glands, weakening of resorption of water with secretory liquids of these glands, which can inhibit processes of vital activity of bees. Decrease in vital activity of bees under the impact of pollutants introduced into the organism with fodder is obviously also related to reduction of intensity of secretions of water from the organism of bees through the covering of the body and respiratory system. It is characteristic that content of plumbum and cadmium was lower in samples of the tissues of bees of the experimental groups compared to the control, but this can indicate the optimizing effect of citrates of argentum and cuprum at the level of these harmful metals in the rectal glands. At the same time, lower concentration of $\mathrm{Pb}$ in the tissues of the head, and also $\mathrm{Pb}$ and $\mathrm{Cd}$ in the abdominal section of honey bees can be conditioned by the antagonistic effect of citrates on metabolism of these elements in their organism (Tyshchenko, 1986).

\section{Conclusions}

Therefore the conducted experimental studies indicate relationship between content of cuprum in the organism of honey bees and other microelements $-\mathrm{Fe}, \mathrm{Zn}, \mathrm{Co}, \mathrm{Pb}$. The determined changes in the content of microelements in the organism of bees manifest tissue specificity and depend on the dose of the additives of citrates of $\mathrm{Ag}$ and $\mathrm{Cu}$ given to the bees. At the impact of argentum in amount of 0.5 and $1.0 \mathrm{mg} / \mathrm{L}$ of sugar syrup, content of ferrum and zinc increases $(\mathrm{P}<0.05)$ in the tissues of the head, and content of lead decreases $(\mathrm{P}<0.05)$ in the abdomen section of the organism of honey bees. At impact of citrate of cuprum in amount of 0.5 and $1.0 \mathrm{mg} / \mathrm{L}$ of sugar syrup, content of ferrum increases $(\mathrm{P}<0.05)$ in the tissues of the thorax and the abdomen, content of cuprum increases $(\mathrm{P}<0.05)$, whereas content of zinc, lead and cadmium decreases $(\mathrm{P}<0.05)$ in the tissues of all anatomic sections of honey bees.

No significant differences in the content of cobalt (except its increase in the abdomen of bees of $\mathrm{V}$ groups) and chromium were found in the tissues of all anatomic sections in conditions of feeding honey bees with citrates such as argentum, as well as cuprum with sugar syrup. Feeding with $\mathrm{Ag}$ and $\mathrm{Cu}$ citrates added to sugar syrup caused a certain correcting effect on the content of such essential microelements as $\mathrm{Fe}, \mathrm{Cu}, \mathrm{Zn}$, and to a lower extent on $\mathrm{Co}$, and also $\mathrm{Pb}$ and $\mathrm{Cd}$ of the head, thorax, and abdomen anatomic sections of the organism of honey bees, which indicates the dose-dependent impact of citrates of $\mathrm{Ag}$ and $\mathrm{Cu}$ in metabolic processes of the organism. This provides a reason to claim that nutrition of honey bees has a determining influence on optimization of parameters of mineral metabolism in different anatomic sections of the organism bees.

\section{References}

Anderson, R. (1987). Chromium. In: Mertz, M. (Ed.). Trace elements in human and animal nutrition. Academic Press, San Diego. Pp. 225-244.

Anton, A., Mathe, P., Radimzky, L., Füleky, G., \& Biczók, G. (1994). Effects of environmental factors and $\mathrm{Mn}, \mathrm{Zn}, \mathrm{Cu}$ trace elements on the soil phosphormonoes terase and amidase activity. Acta Biologica Hungarica, 45(1), 39-50.

Baker, A., Harvey, L., Majask-Newman, G., Fairweather-Tait, S., Flynn, A., \& Cashman, K. (1999). Effect of dietary copper intakes on biochemical marcers of bone metabolism in healthy adult males. European Journal of Clinical Nutrition, 53(5), 408-412.

Bogdanov, S., Haldimann, M., Luginbuhl, W., \& Gallmann, P. (2007). Minerals in honey: Environmental, geographical and botanical aspects. Jornal of Apicultural Research and Bee World, 46(4), 269-275.

Borysevuch, V. B., Kaplynenko, V. G., \& Kosinov, N. V. (2012). Nanomatarialy i nanotechnologii $\mathrm{v}$ veterynarnoy practike [Nanomaterials and nanotechnologies in veterinary practice]. VD Avitsena, Kyiv (in Russian).

Brodschneider, R., \& Crailsheim, K. (2010). Nutrition and health in honey bees. Apidologie, 41(3), 278-294.

Chekman, I. S. (2011) Nanofarmakolohiya [Nanopharmacology]. Zadruha, Kyiv (in Ukrainian).

Conti, M. E., \& Botre, F. (2001). Honey bees and their products as potential bioindicators of heavy metals contamination. Environmental Monitoring and Assessment, 69(3), 267-282.

Dolaychuk, O. P., Fedoruk, R. S., Kovalchuk, I. I., \& Kropyvka, S. I. (2015). Physiological and biochemical processes in the organisms of rats when feeding them with different amounts of germanium citrate. The Animal Biology, 17(2), 50-56. 
Finch, C. A., \& Huebers, H. (1982). Perspectives in iron metabolism. The New England Journal of Medicine, 306, 1520-1528.

Harris, E. D. (2000). Cellular copper transport and metabolism. Annual Review of Nutrition, 20, 291-310

Iskra, R. Y., Vlizlo, V. V., Fedoruk, R. S., \& Antonyak, G. L. (2014). Crom u zhyvlenni tvaryn [Chrome in animal nutrition]. Ahrarna Nauka, Kyiv (in Ukrainian).

Kabata-Pendias, A. (2011). Trace elements in soils and plants. 4th edition. CRC Press, Boca Raton.

Kovalchuk, I. I., \& Fedoruk, R. S. (2008). Melliferous bees and honey are bioindicator contamination of environment by heavy metals. The Animal Biology, $10(1-2), 24-32$.

Kovalskyi, Y., Gucol, A., Gutyj, B., Sobolev, O., Kovalska, L., \& Mironovych, A. (2018). Features of histolism and hystogenesis in the vital temperature range in the organism of honey bee (Apis mellifera L.) in the postembrional period. Ukrainian Journal of Ecology, 8(2), 301-307.

Lebedev, V., \& Bilash, N. (1991). Biologija medonosnoj pchely [Honey bee biology]. Agopromizdat, Moscow (in Russian).
Mazo, V. K., \& Shyrina, L. I. (2005). Medyi v pitanii cheloveka: Vsacyvanie i biodostypnost [Copper in human nutrition: Absorption and bioavailability] Voprocy Pitaniya, 74(2), 52-59 (in Russian).

McDowell, L. R. (2003). Minerals in animal and human nutrition. Elsevier Health Sciences.

Nasolodin, V. V., Dvorkin, V. A., \& Kurkova, S. D. (1994). Biodostypnost microelementov i vzaemodeystvie ih $\mathrm{v}$ prozesse obmena $\mathrm{v}$ organizme [The bioavailability of trace elements and their interaction in the process of exchange in the body]. Gigiena i Sanitariya, 9, 12-14 (in Russian).

Terzic, L., Terzic, V., Krunic, M., \& Brajkovic, M. (1984). Honey bee poisoning caused by arsenic from copper smelter smoke. Acta Veterinaria, 34(1), 54-62.

Tyshhenko, V. (1986). Fiziologija nasekomyh [Physiology of insects]. Vysshaja Shkola, Moscow (in Russian).

Vincent, J. B. (2007). The nutritional biochemistry of chromium (III). Department of Chemistry the University of Alabama Tuscaloosa, USA.

Vishchur, V. Y., Saranchuk, I. I., \& Gutyj, B. V. (2016). Fatty acid content of honeycombs depending on the level of technogenic loading on the environment. Visnyk of Dnipropetrovsk University, Biology, Ecology, 24(1), 182-187. 